Open Access

\title{
Farmgate versus market centre sales: a multi-crop approach
}

\author{
Benjamin Musah Abu, Haruna Issahaku and Paul Kwame Nkegbe* (D)
}

\author{
* Correspondence: \\ pnkegbe@uds.edu.gh \\ Department of Economics and \\ Entrepreneurship Development, \\ Faculty of Integrated Development \\ Studies, University for Development \\ Studies, P O Box 520 Wa, Ghana
}

\begin{abstract}
Smallholder farmers have two basic decisions to make regarding selling their surplus produce: selling at farmgate at low prices or travelling to a market centre where higher prices are offered while incurring some transaction costs. Whichever decision is made has implications for poverty alleviation efforts. Previous studies have ignored modelling participation and market choice simultaneously. Taking a multi-crop approach, this paper fills the gap by investigating the key determinants of market participation decisions of smallholder farmers in Ghana using the sample selectivity probit model in order to account for potential endogeneity and selectivity bias and thus obtain unbiased estimates. Household survey data in the Upper West region of Ghana for the 2011 production season are used to achieve the goal of the study. The results reveal that yields of maize and groundnut and market information are the simultaneous determinants of market participation decisions while age of the farmer, yields of the two crops, membership of farmer organisation and prices of the two crops simultaneously determine the choice of market. These imply that policies that enhance productivity of these smallholders and market information are vital in the drive for a commercially oriented agriculture. Also, the incentives to incur transaction costs to market centres to benefit from remunerative prices lie in measures to increase yields.
\end{abstract}

Keywords: Market participation, Smallholder farmers, Transaction costs, Sample selectivity probit, Ghana

\section{Background}

It has been generally agreed that the way forward for smallholder farmers is increased market participation. Institutions, policymakers and scholars alike continue to emphasise the role of markets in the development of smallholders. For example, Olwande and Mathenge (2012) argue that any pathway that can lift large numbers of the rural poor out of poverty will require some form of transformation of smallholder agriculture into a more commercialised production system. Also, the Ministry of Food and Agriculture's (MoFA) Ghana Commercial Agriculture Project (GCAP) emphasises the importance of graduating from a subsistence-based smallholder system to a sector characterised by a stronger market-based orientation based on a combination of productive smallholders. Consistent with this, Siziba et al. (2011) observe that markets are the pivotal point in the agricultural transformation process.

The increased emphasis on market access relates to its potential to help smallholder farmers break the poverty trap that ensnares them. Several studies (e.g. Al-Hassan et al. 2006;

(C) 2016 The Author(s). Open Access This article is distributed under the terms of the Creative Commons Attribution 4.0 International License (http://creativecommons.org/licenses/by/4.0/), which permits unrestricted use, distribution, and reproduction in any medium, provided you give appropriate credit to the original author(s) and the source, provide a link to the Creative Commons license, and indicate if changes were made. 
Omiti et al. 2009; Jari and Fraser 2009; Siziba et al. 2011) highlight better incomes and prospects of reducing poverty, sustainable livelihoods, creation of the necessary demand, offering of remunerative prices, expanded production and the attendant adoption of productivity-enhancing technologies and increased economic diversification as some of the benefits of markets to small scale farmers. Muamba (2011) adds that greater market participation will promote the transformation of the farmers' economic status from subsistent or semi-subsistent to specialised farmers where they produce only crops for which they have a comparative advantage. In view of these benefits, the growing realisation of stimulating market participation of poor farmers for the goal of poverty alleviation cannot be overemphasised.

However, market participation decisions affect the extent of poverty alleviation. There are two basic decisions that are open to smallholders in their quest to be market participants: selling at farmgate or selling at a designated market centre. These two decisions are key determinants of the effectiveness of the market system in poverty alleviation. The decision of farmers to participate in the market through the vent of farmgate continues to hamper poverty mitigating efforts. For example, Fafchamps and Hill (2005) indicate that selling at the farmgate is mostly less remunerative. That is, farmgate prices are usually low such that significant gains can be made if sufficient quantities are put out for sale, and given the low productivity of smallholders, there is no doubt that such gains from farmgate would continue to elude them. The problems of the farmgate system of market participation have led to calls for policies to provide price incentives to encourage farmers to sell their harvest at the market rather than at the farmgate (Muamba 2011). Fafchamps and Hill (2005) also note the raising of welfare of farmers through institutional packages such as producer cooperatives as means of avoiding lower prices through the farmgate.

The implication of this is that the orientation of policies towards access to market as a means of fast tracking the development of smallholders should be well defined to exclusively relate to market centre participation rather than either farmgate or market centre participation. In other words, market participation can be beneficial if participants engage in market centre sales where prices are higher than at the farmgate where sale is more of a giveaway. It is worth noting that market centre sale comes with its concomitant transaction costs. That notwithstanding, the wedge between farmgate and market centre prices is usually large enough to cover transaction costs such that market centre is still remunerative than farmgate.

Previous studies have surprisingly ignored modelling participation and market choice simultaneously. This study represents the first attempt and for that matter contributing to the existing literature by implementing a single-stage estimation of the dual problem of participation and market choice of smallholder farmers. We perform the analyses while taking account of endogeneity and sample selection bias. We note also that the literature on market participation in Ghana is nascent. As a result, there is insufficient empirical literature on farmers' dilemma to sell at the farmgate or transport their produce to market centres (Fafchamps and Hill 2005). The few existing studies on the subject in Ghana relate to the factors influencing the probability and the quantity of sale (see Martey et al. 2012; Abu et al. 2014). By estimating participation and market choice simultaneously, our work differs from the studies of Martey et al. (2012) and Abu et al. (2014). Though the work of Abu et al. (2014) employs a two-step modelling 
approach, the second stage of the model captures volume of sale rather than choice of market.

The Upper West region is one of the poorest and least developed in Ghana having the least average annual per capita income of GH\$3015.7 as against the national average of GH45346.9 (Ghana Statistical Service 2014). ${ }^{1}$ Implementing this study in the region is therefore justified. Also, maize and groundnut are chosen for the study due to the fact that they are two of the major crops grown (Ministry of Food and Agriculture 2011) and are of high commercial value in the region.

The rest of the paper is presented as follows. We review related literature on market participation where gaps in these studies are identified. Next, we present the methodology employed, highlighting the study area and data, and methods of data analysis. Estimation results and discussions are presented next. Finally, the conclusion is presented which highlights a summary of the findings and policy implications.

\section{Literature review}

Insight into farmgate and market selling dynamics by agricultural households is provided by Furlong and Slotsve (1983) in their exposition of pickup and delivery pricing. The characteristics of pickup and delivery pricing correspond to the farmgate and market centre pricing, respectively, in smallholder marketing. In the smallholder setting, farmers decide to sell at the farmgate or travel to the market and indirectly choose a pickup price or a delivery price. According to Furlong and Slotsve (1983), pickup prices are characterised by discounts. This basically implies that the variant of discounts in farmgate marketing is the lower prices offered. Farmers avoid transaction costs to reach markets but have to offer 'discounts' to buyers who incur such costs to buy at lower prices (pickup prices). However, farmers who decide to incur transaction costs reach markets and then sell at higher prices (delivery prices). The wedge, therefore, between farmgate and market prices is accounted for by transaction costs. The two types of transaction costs, namely fixed and proportional, lead to a low farmgate price at which farmers can sell their crop and a higher price at which they sell that crop at the market (Vance and Geoghegan 2004).

Market participation is viewed as a two-stage phenomenon and hence embodies two decision processes (Goetz 1992; Bellemare and Barrett 2006). First, households decide whether to be net buyers, net sellers or autarchic in the market for that commodity. This is the participation stage. Second, net buyers and net sellers determine the extent or intensity of participation. This is the intensity stage. In the literature, there are two distinct studies: first, those studies that model determinants of participation and intensity and, second, those that model participation and whether households choose to sell at farmgate or market centre. Quite recently, Burke et al. (2015) introduced a third dimension, the triple hurdle approach, which models in the first stage whether a farmer produced a particular crop while the second and third stages maintain the participation and intensity stages.

Three econometric procedures are distinguished in market participation studies. These are the one-step, the two-step and the three-step approaches. The one-step approach is where the focus is on modelling the determinants of the intensity stage. Some econometric models used in the one-step approach include Tobit and truncated 
regression models. ${ }^{2}$ For example, Omiti et al. (2009) use a truncated regression while Holloway et al. (2000, 2001a) and Martey et al. (2012) use Tobit models to model intensity of participation. An underlying assumption of the one-step approach is that the same set of variables determines both the participation and intensity stages (Alene et al. 2008). This assumption is not only restrictive but erroneous since it is possible that a variable could have different effects on participation and intensity of participation (Wooldridge 2002; Ricker-Gilbert et al. 2011; Olwande and Mathenge 2012).

The two-step approach simultaneously or sequentially models participation and intensity, thus helping to resolve the limitation inherent in the single-step approach. Prominent two-step models are the Heckman sample selection and the double hurdle models. Goetz (1992), Makhura et al. (2001), Boughton et al. (2007), Alene et al. (2008) and Siziba et al. (2011) have applied the Heckman model to explain the determinants of participation and intensity. The model estimates a first-stage probit of participation decision, derives an inverse mills ratio (IMR) and then estimates a second-stage ordinary least squares (OLS) with the IMR as a variable to account for selectivity bias. The advantage of the Heckman model is its ability to model the two stages simultaneously and to correct for selectivity bias. However, the appropriateness of the model for participation is questionable. First, according to Ricker-Gilbert et al. (2011), the Heckman model is designed for incidental truncation, where the zeros are unobserved values. However, in market participation studies, a zero value in the data would reflect farmers' optimal choice rather than a missing value (Reyes et al. 2012). It is therefore erroneous to equate these missing observations to zero (Olwande and Mathenge 2012). Second, the second-stage OLS is questionable since it is not known whether the underlying assumptions of OLS are met.

Some other studies (see, for example, Holloway et al. 2005; Olwande and Mathenge 2012; Reyes et al. 2012; Abu et al. 2014) analyse participation and intensity using the double hurdle model. This model estimates a first-stage probit and a second-stage truncated regression. The fundamental assumption underlying the model is that the participation and the intensity stages are independent. Based on this, Smith (2003) argues that assuming dependency between the two equations is not a worthwhile exercise since there is little statistical information available to support dependency in the double hurdle framework. One advantage of the double hurdle model is its ability to nest the Tobit model, thus allowing for the testing of the restrictions implied by the Tobit hypothesis (Olwande and Mathenge 2012). The limitation of the model is inherent in the independence assumption. It is inappropriate to assume that participation and intensity are independent. It is worth noting that though the two-step approaches possess some weaknesses, they are by far better than the one-step approaches. Also, the double hurdle model, despite its weaknesses, is theoretically more plausible to use as compared to its Heckman counterpart.

As mentioned already, the three-step approach is a recent introduction to the literature by Burke et al. (2015) which argues for the introduction of non-producers in the first stage and thus overcomes the weakness of the two-step approach to handle the three stages.

In terms of econometric methodology, frequentist approaches have inundated participation studies and have gained more currency than Bayesian approaches. We note some contributions of Bayesian approaches. Holloway et al. (2001a, b, 2004, 2005, 2008) are notable applications of Bayesian methodology to market participation. Bayesian 
methodology is usually underpinned by the use of the Markov Chain Monte Carlo (MCMC) method especially the use of the Gibbs sampler (see Gelfand and Smith 1990; Casella and George 1992 for exposition on the Gibbs sampler proposed by Tanner and Wong 1987) to augment data. Another notable contribution is on thresholds where an unknown or random censoring of data is considered instead of the widely used zero censoring threshold. Significant empirical participation studies on this innovative random censoring are provided by Holloway et al. (2000, 2001a, 2004, 2005). In fact, one of the most significant contributions of these non-zero threshold studies is their ability to estimate how far nonparticipating households are from levels of marketable surplus that would encourage and sustain participation. Holloway et al. (2004) find that the zero censoring overstates estimates.

With respect to participation and choice of market, the focus of this study, Fafchamps and Hill (2005) were the first to model whether farmers sell to itinerant traders or directly to markets. They adopted a detailed econometric procedure involving multiple estimations using probit, instrumenting regressions and Tobit models. A number of methodological issues arise from this pioneering study. First, they fail to consider the decision of a farmer to either sell or not. They consider the decision to sell to either market centre or farmgate in the first estimation (ignoring farmers not selling at all) using a probit model. This introduces the problem of truncation and hence resulting in biased and inconsistent estimates. Second, other estimations involve single equations with a number of continuous dependent variables (output, interaction of output and wealth and distance travelled to market). This makes the approach ad hoc, failing to provide a definite procedure for easy replication. Also, the likelihood of getting lost in the estimation procedures is very high. Third, they fail to adopt a two-stage approach simultaneously modelling participation and choice of market.

Muamba (2011) followed up by developing a farm level sequential model taking account of the conditional nature of farmers' decision to participate in the market. While the author adopts an innovative approach to estimating a bivariate probit to account for sample selection and a system of seemingly unrelated regressions, two issues are identified with the approach. First, just like Fafchamps and Hill (2005), the study fails to consider the initial decision of a farmer to either sell or not. Second, the application of the bivariate probit does not account for participation and choice of market. In effect, Muamba (2011) analyses the choice of market and the intensity of participation. A recent introduction of the triple hurdle model by Burke et al. (2015) extends the literature so far. However, it fails to account for choice of market.

To the best of our knowledge, this study is the first attempt at simultaneously estimating participation and choice of market. Thus, our contribution to the existing literature is that, instead of ignoring farmers who do not sell, we model a first-stage equation of factors determining the decision of farmers to sell either maize or groundnut. We then, in a second stage, model the decision to sell either at farmgate or market centre. This implies that what we model in the second stage is what is modelled in the first stages of Fafchamps and Hill (2005) and Muamba (2011). Since the first and second stages are discrete outcomes, none of the two-step approaches explored earlier is applicable. We adopt the sample selectivity probit model to deal with the situation at hand. The sample selectivity probit model assumes that the error terms in the participation and market choice stages are correlated and normally distributed, and this is also its weakness as there 
is no formal procedure for verifying this. Despite this weakness, it is still useful when modelling two discrete outcomes in a single process.

Two assumptions underpin market participation studies: simultaneous and sequential decision-making. Key et al. (2000) assume that households make simultaneous decisions. This implies that households predetermine either the quantity of sale or choice of market, depending on the study type, before they get to know the information available to them about these choices. The simultaneous decision-making gives traders market power over selling households rendering them vulnerable to exploitation by traders (Bellemare and Barrett 2006). On the other hand, Goetz (1992) and Holloway et al. (2005) assume sequential decision-making, an observation subsequently confirmed empirically by Bellemare and Barrett (2006). The sequential decision-making implies that households make decisions after receiving information from the market. They therefore retain greater flexibility over market decisions, hence reducing traders' capacity to extract much or all the gains from trade (Bellemare and Barrett 2006).

\section{Methods}

Study area and data

This study was conducted in the Upper West region of Ghana involving four agricultural districts: Jirapa-Lambussie, Nadowli, Wa West and Sissala East. Data were collected from 400 farmers (200 each from independent maize and groundnut farmers). For each district, 80 farmers (40 each for the two crops) were selected except for the Jirapa-Lambussie district where 160 farmers were selected because, at the time of data collection, Lambussie-Karni district had not been separated from the Jirapa district.

The drawing of the sample involved the use of a multi-stage sampling procedure in three steps. In the first stage, the four districts were selected based on the fact that they had the highest share in the production of maize and groundnut in the 2011 production season. The second stage narrowed down to specific communities known for the production of the two commodities. The selection was done in consultation with the various selected district offices of MoFA. This was to prevent a random sample of operational areas where maize and groundnut are not intensively cultivated. The third stage involved the selection of respondents. To prevent bias, stratified sampling procedure was employed to create two strata of the population based on gender. The rationale for this stratification was to ensure a proportionate representation of male and female farmers. A semi-structured questionnaire was then administered to the chosen respondents.

\section{Analytical method}

As has been established in the market participation literature, studies typically adopt two-step analytical approach to cater for the unobserved decision to participate and the observed degree or extent of participation. The innovation we table is to model the unobserved decision to participate and the observed choice of participation decision (that is, either selling at farmgate or selling at a market centre). Two problems are anticipated in this analytical framework. First, since nonparticipants are not considered in the second-stage market choice model, proceeding with a univariate probit model would introduce sample selection bias $^{3}$ since farmers would self-select into treatment 
(Faltermeier and Abdulai 2009). Second, the decision of a maize or groundnut farmer to sell either at the farmgate or market centre is conditional on the decision to participate in the market (i.e. the first-stage). Implementing a univariate probit to model the second stage will lead to biased results due to the potential endogenous nature of participating in the market and the choice of market. ${ }^{4}$ An appropriate model requires that selectivity and endogeneity are taken into account.

The bivariate probit model is capable of solving the endogeneity problem. However, it is unable to handle the selectivity bias. We therefore rely on sample selectivity probit model to overcome these problems. The sample selectivity probit model is adopted as it has an intrinsic ability to account for selectivity bias and make corrections simultaneously, as well as deal with endogeneity. This model's ability to handle selectivity bias is acclaimed. It simultaneously implements the first and second stages and provides a likelihood ratio test of a rho $(\rho)$ parameter which indicates the relationship between the two equations. The significance of $\rho$ indicates the existence of selectivity bias, and an internal correction of this bias is provided.

Just like other market participation studies, this study is underpinned by the linear random utility assumption (Greene 2008). The rationale for the linear random utility assumption is that an individual faces a choice between two or more alternatives and chooses the alternative which gives the highest utility. This is usually represented as

$$
\left\{\begin{array}{l}
U_{i 0}=X_{i}^{\prime} \beta_{i 0}+e_{i 0} \\
U_{i 1}=X_{i}^{\prime} \beta_{i 1}+e_{i 1}
\end{array}\right.
$$

where $U_{i j}$ measures utility gained by farmer $i$ from choosing alternative $j$ (with the decision not to participate in the market represented by $U_{i 0}$ while participating is represented by $\left.U_{i 1}\right), X_{i}$ is a vector of characteristics specific to farmer $i$ and attributes associated with alternative $j$ and specific to the $i$ th farmer, $\beta$ is a vector of unknown parameters, and $e_{i j}$ is random disturbance related to the choice of alternative $j$ by farmer $i$.

The probability that a farmer chooses an alternative (that is, $Y_{i}=1$ ) as against another (that is, $Y_{i}=0$ ) is associated with the probability distribution of the error differences in the expected utilities from the choices and given by

$$
P_{i}=\operatorname{Prob}\left(Y_{i}=1 \mid X\right)=\operatorname{Prob}\left(y_{i}^{*}>0 \mid X\right)=\operatorname{Prob}\left[e_{i}>-X_{i}^{\prime} \beta \mid X\right]=F\left(X^{\prime} \beta\right)
$$

where $F$ is the cumulative distribution function of $e_{i}\left(=e_{i 1}-e_{i 0}\right)$ evaluated at $X_{i}^{\prime} \beta$, and $y_{i}^{*}\left(=U_{i 1}-U_{i 0}\right)$ is a latent variable, since it is unobservable, and is linked to $y_{i}$, the observed binary variable, through the relation

$$
\left\{\begin{array}{l}
1 \text { if } y_{i}^{*}>0 \\
0 \text { otherwise }
\end{array}\right.
$$

To specify a model that describes how the probability of choosing an alternative and the explanatory variables are related depends on the assumption made about the distribution of the error term. The normal and logistic distributions corresponding to probit and logit models, respectively, are the two mostly assumed distributions in the literature. 
Assuming a normal distribution of the error term in the utility model, a probit model can be relied on for analysis. In that case and linking up with Eq. (2), the probability function of choosing an alternative versus another is given by

$$
P_{i}=\operatorname{Prob}\left[Y_{i}=1 \mid X\right]=\int_{-\infty}^{X_{i}^{\prime} \beta} \varnothing(t) d t=\Phi\left(X_{i}^{\prime} \beta\right)
$$

with $\varnothing()=.(2 \pi)^{0.5} \exp \left(-t^{2} / 2\right)$ and $\Phi($.$) being the density and cumulative distribution$ functions, respectively, of a standard normal random variable.

In the sample selectivity probit model, just like a bivariate probit model, the assumption of correlated normally distributed error terms in a two-equation system leads to

$$
\left\{\begin{array}{lll}
y_{i 1}^{*}=X_{i 1}^{\prime} \beta_{1}+e_{i 1}, & Y_{i 1}=1 \text { if } y_{i 1}^{*}>0, & \text { and } 0 \text { otherwise } \\
y_{i 2}^{*}=X_{i 2}^{\prime} \beta_{2}+e_{i 2}, & Y_{i 2}=1 \text { if } y_{i 2}^{*}>0, & \text { and } 0 \text { otherwise }
\end{array}\right.
$$

where $e_{i j}$ is the normally distributed error term, $E\left[e_{i 1} \mid x_{i 1}, x_{i 2}\right]=E\left[e_{i 2} \mid x_{i 1}, x_{i 2}\right]=0$, $\operatorname{Var}\left[e_{i 1} \mid x_{i 1}, x_{i 2}\right]=\operatorname{Var}\left[e_{i 2} \mid x_{i 1}, x_{i 2}\right]=1$, and $\operatorname{Cov}\left[e_{i 1}, e_{i 2} \mid x_{i 1}, x_{i 2}\right]=\rho$. For a typical farmer, $Y_{i 1}$ is not observed unless $Y_{i 2}=1$. The appropriate conditional probability, derived by modifying that of bivariate model, is given by Greene (2008) as

$$
\operatorname{Prob}\left[Y_{i 1}=1 \mid Y_{i 2}=1\right]=\frac{\Phi_{2}\left(x_{i 1}^{\prime} \beta_{1}, x_{i 2}^{\prime} \beta_{2}, \rho\right)}{\Phi\left(x_{i 2}^{\prime} \beta_{2}\right)}
$$

Following from Eq. (6), the unconditional probabilities for the three kinds of observed outcomes in the model are given as follows:

$$
\left\{\begin{array}{l}
Y_{i 2}=0: \operatorname{Prob}\left(Y_{i 2}=0 \quad \mid x_{i 1}, x_{i 2}\right)=1-\Phi\left(x_{i 2}^{\prime} \beta_{2}\right) \\
Y_{i 1}=0, Y_{i 2}=1: \operatorname{Prob}\left(Y_{i 1}=0, Y_{i 2}=1 \mid x_{i 1}, x_{i 2}\right)=\Phi_{2}\left(-x_{i 1}^{\prime} \beta_{1}, x_{i 2}^{\prime} \beta_{2},-\rho\right) \\
Y_{i 1}=1, Y_{i 2}=1: \operatorname{Prob}\left(Y_{i 1}=1, Y_{i 2}=1 \mid x_{i 1}, x_{i 2}\right)=\Phi_{2}\left(x_{i 1}^{\prime} \beta_{1}, x_{i 2}^{\prime} \beta_{2}, \rho\right)
\end{array}\right.
$$

where $\Phi$ and $\Phi_{2}$ are, respectively, univariate and bivariate normal cumulative distribution functions.

The probabilities above thus enter the log-likelihood function given by

$$
L_{i}=\sum \ln \left[1-\Phi\left(x_{i 2}^{\prime} \beta_{2}\right)\right]+\sum \ln \left[\Phi_{2}\left(-x_{i 1}^{\prime} \beta_{1}, x_{i 2}^{\prime} \beta_{2},-\rho\right)\right]+\sum \ln \left[\Phi_{2}\left(x_{i 1}^{\prime} \beta_{1}, x_{i 2}^{\prime} \beta_{2}, \rho\right)\right]
$$

The maximum likelihood approach is then used to estimate selectivity probit model. The description, measurement and expected signs of variables are presented in Table 1.

As noted by Greene (2008), several 'marginal effects' can be evaluated in a typical bivariate probit, but an interesting step usually involves examining the derivatives of the conditional mean functions. In the light of this, a basic marginal effect function can be stated as

$$
\frac{\partial E\left[Y_{1} \mid Y_{2}=1, X\right]}{\partial X}=\frac{\partial\left[\operatorname{Prob}\left(Y_{1}=1 \mid Y_{2}=1, X\right)\right]}{\partial X}=\frac{\partial}{\partial X}\left[\frac{\Phi_{2}\left(X^{\prime} \gamma_{1}, X^{\prime} \gamma_{2}, \rho\right)}{\Phi\left(X^{\prime} \gamma_{2}\right)}\right]
$$

where $\Phi_{2}$ and $\Phi$ are as already defined, $\gamma_{j}$ contains all non-zero elements of $\beta_{j}$ and likely to also contain some zeros in the positions of variables that appear in only one of the two equations, and $j=1,2$. For a dummy explanatory variable, however, the 
Table 1 Description, measurements and expected signs of variables

\begin{tabular}{|c|c|c|c|}
\hline Variable & Description & Measurement & $\begin{array}{l}\text { Expected } \\
\text { sign }\end{array}$ \\
\hline \multicolumn{4}{|c|}{ Dependent variables } \\
\hline PART & $\begin{array}{l}\text { Binary variable indicating the decision } \\
\text { to participate in the market or not }\end{array}$ & $\begin{array}{l}\text { Dummy: } 1 \text { = farmer participates in market } \\
\text { (sold maize/groundnut); } 0=\text { otherwise }\end{array}$ & \\
\hline POS & $\begin{array}{l}\text { Binary variable indicating the decision } \\
\text { to sell to the market centre or farmgate }\end{array}$ & Dummy: 1 = market centre; $0=$ farmgate & \\
\hline \multicolumn{4}{|c|}{ Independent variables } \\
\hline AGE & Age of farmer & Number of years & $+/-$ \\
\hline GEN & Gender of farmer & Dummy: $1=$ if male; $0=$ otherwise & + \\
\hline EDUC & Educational level of farmer & Number of years of schooling & $+/-$ \\
\hline MARST & Marital status of farmer & Dummy: 1 = if married; $0=$ otherwise & $+/-$ \\
\hline HHSIZE & Household size of farmer & Number of people in the household & $+/-$ \\
\hline MFBO & $\begin{array}{l}\text { Membership of farmer to farmer-based } \\
\text { organisation }\end{array}$ & Dummy: $1=$ if member; $0=$ otherwise & + \\
\hline YIELD & $\begin{array}{l}\text { Yield of maize or groundnut in the } \\
2011 \text { production season }\end{array}$ & Ratio of output to farm size & + \\
\hline ACCRE & Access to credit by farmer & $\begin{array}{l}\text { Dummy: } 1=\text { if farmer applied and } \\
\text { received credit; } 0=\text { otherwise }\end{array}$ & + \\
\hline MKTINFO & Farmer's access to market information & Dummy: $1=$ if yes; $0=$ otherwise & + \\
\hline EXTCON & Access to extension services & Dummy: $1=$ if yes; $0=$ otherwise & + \\
\hline PRICE & Average price of maize or groundnut sold & Ghana Cedi (GHç) per kg & + \\
\hline FOS & Form of sale of groundnut & Dummy: $1=$ shelled; $0=$ unshelled & $+/-$ \\
\hline
\end{tabular}

marginal effect is determined by using a modified form of Eq. (9) which will reflect discrete changes in the predicted probabilities.

\section{Results and discussion}

Descriptive statistics of households are presented in Table 2. From the table, the mean ages of maize and groundnut farmers are 47 and 42 years, respectively. About 86 and $80 \%$ of maize and groundnut farmers are, respectively, male. Average years spent in school are 3 and 2, respectively. The average farm size cultivated is 1.10 ha for maizeproducing farmers and 1.22 ha for groundnut-producing farmers with mean outputs of 550.88 and $520.21 \mathrm{~kg}$, and average yields of 466.58 and $369.91 \mathrm{~kg} / \mathrm{ha}$, respectively. With respect to market participation, $48.5 \%$ of maize-producing households sell maize while $83.5 \%$ of groundnut-producing households sell groundnut. About 31.5 and $48.5 \%$ of maize and groundnut are sold at the farmgate. The average prices received by maize and groundnut farmers are GH\$1.37 and GH\$1.67 per kg, respectively.

The results of the determinants of market participation and the choice of market are displayed in Table 3. The Wald chi-square values of both models show that the explanatory variables in the participation and choice equations in both the maize and groundnut models jointly explain participation and choice of market. ${ }^{5}$ The significance of the likelihood ratio tests of the rho parameter in both models suggests two things. First, the sample selectivity probit model is preferred to univariate probit models, since the results indicate the existence of sample selection bias if the second-stage equations were estimated alone. Fortunately, the model has an internal system of correcting for this bias. Therefore, the estimates are unbiased and consistent. Second, it shows that 
Table 2 Descriptive statistics of variables

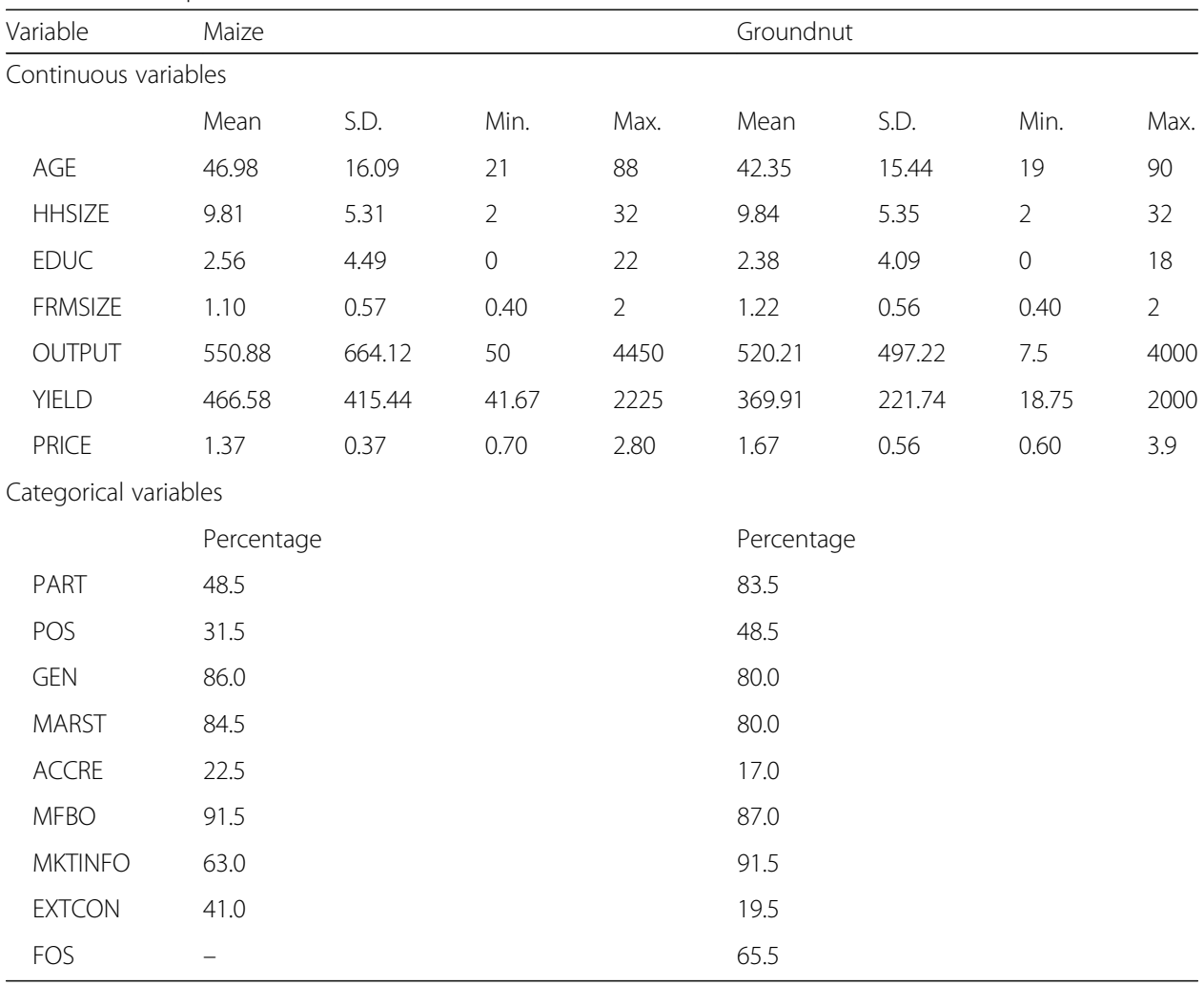

market participation and choice of market decisions are made simultaneously, which confirms the work of Key et al. (2000) who assume simultaneous market decisions of households, but contradicts the work of Goetz (1992), Holloway et al. (2005) and Bellemare and Barrett (2006) who assume sequential market decisions of households. This means that households predetermine the choice of farmgate or market centre before realising the information available to them about these choices. According to Bellemare and Barrett (2006), the simultaneous decision-making gives traders market power over selling households rendering them vulnerable to exploitation by traders. This is opposed to the sequential decision assumption where households retain greater flexibility over market decisions, hence reducing traders' capacity to extract much or all the gains from trade (Bellemare and Barrett 2006).

In Table 3, the signs of all the determining variables of market participation and choice of market by maize-producing households, except education and extension services, respectively, are consistent with expectations. For groundnut-producing households, all the variables are consistent with expectations in both the participation and the choice of market models.

We find that as age of the farmer increases, the likelihood of selling maize declines by $1.1 \%$. This is consistent with the finding of Boughton et al. (2007), Siziba et al. (2011), Olwande and Mathenge (2012) and Burke et al. (2015). Perhaps, older farmers expect to remain food secure and would not want to take the risk of emptying their maize barns as against the younger farmers who expect to enhance their quality of life through incomes from market engagements. The fact that maize is a consumption commodity or staple in Ghana supports this explanation. For choice of market, age is 
Table 3 Sample selectivity probit estimates of determinants of market participation and market choice

\begin{tabular}{|c|c|c|c|c|c|c|c|c|}
\hline \multirow[t]{3}{*}{ Variable } & \multicolumn{4}{|l|}{ Maize } & \multicolumn{4}{|l|}{ Groundnut } \\
\hline & \multicolumn{2}{|c|}{ Participation } & \multicolumn{2}{|c|}{ Market choice } & \multicolumn{2}{|l|}{ Participation } & \multicolumn{2}{|c|}{ Market choice } \\
\hline & Coefficient & $\begin{array}{l}\text { Marginal } \\
\text { effect }\end{array}$ & Coefficient & $\begin{array}{l}\text { Marginal } \\
\text { effect }\end{array}$ & Coefficient & $\begin{array}{l}\text { Marginal } \\
\text { effect }\end{array}$ & Coefficient & $\begin{array}{l}\text { Marginal } \\
\text { effect }\end{array}$ \\
\hline AGE & $\begin{array}{l}-0.0286^{a} \\
(0.0083)\end{array}$ & $\begin{array}{l}-0.0112 \\
(0.0033)\end{array}$ & $\begin{array}{l}-0.0276^{a} \\
(0.0100)\end{array}$ & $\begin{array}{l}-0.0078 \\
(0.0031)\end{array}$ & $\begin{array}{l}-0.0084 \\
(0.0113)\end{array}$ & $\begin{array}{l}-0.0001 \\
(0.0002)\end{array}$ & $\begin{array}{l}-0.0225^{b} \\
(0.0118)\end{array}$ & $\begin{array}{l}-0.0090 \\
(0.0047)\end{array}$ \\
\hline GEN & $\begin{array}{l}0.4470 \\
(0.3950)\end{array}$ & $\begin{array}{l}0.1768 \\
(0.1543)\end{array}$ & $\begin{array}{l}0.3923 \\
(0.5025)\end{array}$ & $\begin{array}{l}0.0972 \\
(0.1093)\end{array}$ & $\begin{array}{l}0.9459^{c} \\
(0.4832)\end{array}$ & $\begin{array}{l}0.0245 \\
(0.0348)\end{array}$ & $\begin{array}{l}-0.3017 \\
(0.5086)\end{array}$ & $\begin{array}{l}-0.0953 \\
(0.2041)\end{array}$ \\
\hline EDUC & $\begin{array}{l}-0.0598^{b} \\
(0.0324)\end{array}$ & $\begin{array}{c}-0.0234 \\
(0.0127)\end{array}$ & $\begin{array}{l}-0.0189 \\
(0.0340)\end{array}$ & $\begin{array}{l}-0.0053 \\
(0.0097)\end{array}$ & $\begin{array}{l}-0.0525 \\
(0.0465)\end{array}$ & $\begin{array}{l}-0.0006 \\
(0.0008)\end{array}$ & $\begin{array}{l}-0.0652 \\
(0.0402)\end{array}$ & $\begin{array}{l}-0.0263 \\
(0.0159)\end{array}$ \\
\hline MARST & $\begin{array}{l}-0.1022 \\
(0.3474)\end{array}$ & $\begin{array}{l}-0.0397 \\
(0.1342)\end{array}$ & $\begin{array}{l}-0.3323 \\
(0.4172)\end{array}$ & $\begin{array}{l}-0.1021 \\
(0.1399)\end{array}$ & $\begin{array}{l}0.0662 \\
(0.4888)\end{array}$ & $\begin{array}{l}0.0008 \\
(0.0060)\end{array}$ & $\begin{array}{l}-0.0961 \\
(0.4390)\end{array}$ & $\begin{array}{c}-0.0374 \\
(0.1742)\end{array}$ \\
\hline HHSIZE & $\begin{array}{l}-0.1072^{a} \\
(0.0300)\end{array}$ & $\begin{array}{l}-0.0420 \\
(0.0119)\end{array}$ & $\begin{array}{l}0.0050 \\
(0.0374)\end{array}$ & $\begin{array}{l}0.0014 \\
(0.0107)\end{array}$ & $\begin{array}{c}-0.0024 \\
(0.0319)\end{array}$ & $\begin{array}{l}-2.59 e^{-} \\
05 \\
(0.0003)\end{array}$ & $\begin{array}{l}0.0765^{c} \\
(0.0335)\end{array}$ & $\begin{array}{l}0.0302 \\
(0.0131)\end{array}$ \\
\hline YIELD & $\begin{array}{l}0.0025^{a} \\
(0.0005)\end{array}$ & $\begin{array}{l}0.0010 \\
(0.0002)\end{array}$ & $\begin{array}{l}0.0009^{c} \\
(0.0004)\end{array}$ & $\begin{array}{l}0.0003 \\
(0.0001)\end{array}$ & $\begin{array}{l}0.0130^{a} \\
(0.0028)\end{array}$ & $\begin{array}{l}0.0001 \\
(0.0002)\end{array}$ & $\begin{array}{l}0.0022^{b} \\
(0.0012)\end{array}$ & $\begin{array}{l}0.0010 \\
(0.0005)\end{array}$ \\
\hline ACCRE & $\begin{array}{l}1.5477^{a} \\
(0.4811)\end{array}$ & $\begin{array}{l}0.4811 \\
(0.0927)\end{array}$ & $\begin{array}{l}0.8197^{a} \\
(0.3000)\end{array}$ & $\begin{array}{l}0.2670 \\
(0.1215)\end{array}$ & $\begin{array}{c}-0.7232 \\
(0.6565)\end{array}$ & $\begin{array}{l}-0.0160 \\
(0.0317)\end{array}$ & $\begin{array}{l}-0.0863 \\
(0.4873)\end{array}$ & $\begin{array}{l}-0.0500 \\
(0.1865)\end{array}$ \\
\hline MKTINFO & $\begin{array}{l}0.7481^{a} \\
(0.2730)\end{array}$ & $\begin{array}{l}0.2905 \\
(0.1024)\end{array}$ & $\begin{array}{l}-0.6561 \\
(0.4191)\end{array}$ & $\begin{array}{l}-0.1962 \\
(0.1355)\end{array}$ & $\begin{array}{l}0.9187^{b} \\
(0.4937)\end{array}$ & $\begin{array}{l}0.0295 \\
(0.0428)\end{array}$ & $\begin{array}{l}0.0875 \\
(0.8415)\end{array}$ & $\begin{array}{l}0.0640 \\
(0.3269)\end{array}$ \\
\hline MFBO & $\begin{array}{l}1.2993 \\
(0.8678)\end{array}$ & $\begin{array}{l}0.3849 \\
(0.1503)\end{array}$ & $\begin{array}{l}1.4231^{\mathrm{c}} \\
(0.5841)\end{array}$ & $\begin{array}{l}0.5103 \\
(0.2079)\end{array}$ & $\begin{array}{c}-0.7104 \\
(0.5089)\end{array}$ & $\begin{array}{l}-0.0165 \\
(0.0276)\end{array}$ & $\begin{array}{l}1.7933^{\mathrm{a}} \\
(0.6487)\end{array}$ & $\begin{array}{l}0.5489 \\
(0.1148)\end{array}$ \\
\hline EXTCON & $\begin{array}{l}0.0881 \\
(0.2552)\end{array}$ & $\begin{array}{l}0.0345 \\
(0.0997)\end{array}$ & $\begin{array}{l}-0.4719^{b} \\
(0.2773)\end{array}$ & $\begin{array}{l}-0.1279 \\
(0.0788)\end{array}$ & $\begin{array}{l}-0.3739 \\
(0.4541)\end{array}$ & $\begin{array}{l}0.0031 \\
(0.0048)\end{array}$ & $\begin{array}{l}0.3491 \\
(0.4152)\end{array}$ & $\begin{array}{l}0.1416 \\
(0.1630)\end{array}$ \\
\hline PRICE & & & $\begin{array}{l}0.7366^{b} \\
(0.4331)\end{array}$ & $\begin{array}{l}0.2075 \\
(0.0822)\end{array}$ & & & $\begin{array}{l}2.7987^{a} \\
(0.5189)\end{array}$ & $\begin{array}{l}1.1071 \\
(0.1989)\end{array}$ \\
\hline FOS & & & & & & & $\begin{array}{l}1.8253^{\mathrm{a}} \\
(0.3885)\end{array}$ & $\begin{array}{l}0.6336 \\
(0.0982)\end{array}$ \\
\hline CONSTANT & $\begin{array}{l}0.3104 \\
(0.6962)\end{array}$ & & $\begin{array}{l}-0.2152 \\
(0.9901)\end{array}$ & & $\begin{array}{l}-3.1013^{a} \\
(0.9559)\end{array}$ & & $\begin{array}{l}-5.1517^{a} \\
(1.5237)\end{array}$ & \\
\hline Rho & & $\begin{array}{l}1.000 \\
(3.86 \times 10\end{array}$ & $-13)$ & & & $\begin{array}{l}-1.000 \\
\left(3.40 \times 10^{-}\right.\end{array}$ & & \\
\hline $\begin{array}{l}\text { Number of } \\
\text { observations }\end{array}$ & 200 & & & & 200 & & & \\
\hline $\begin{array}{l}\text { Censored } \\
\text { observations }\end{array}$ & 103 & & & & 33 & & & \\
\hline Wald $x^{2}$ & $39.28^{a}$ & & & & $45.08^{a}$ & & & \\
\hline Log likelihood & -110.476 & & & & -76.0244 & & & \\
\hline $\begin{array}{l}\text { Likel. ratio test } \\
\text { of } \rho x^{2}(1)\end{array}$ & $6.37^{c}$ & & & & $6.61^{c}$ & & & \\
\hline
\end{tabular}

Source: Regression estimates from household survey data, 2012. Note: standard errors in parentheses

${ }^{a}$ At $1 \%$

${ }^{\mathrm{b}}$ Denotes statistical significance at $10 \%$

${ }^{\mathrm{c}}$ At $5 \%$

negatively correlated with maize and groundnut market choices. For an additional year of a farmer, the probability of choosing market centre sale decreases by 0.8 and $0.9 \%$ for maize and groundnut producers, respectively. This is consistent with Muamba's (2011) notion that older farmers have less physical ability to carry the crops to the market. It seems plausible that the progressive mindedness and adventurous nature of younger farmers would encourage and stimulate them to incur transaction costs to reach market centres where they can fetch higher prices, consistent with the notion by 
Enete and Igbokwe (2009) that older farmers are more risk averse in exploring market sales.

Gender is a positive determinant of groundnut market participation, as we find that male farmers are $2.5 \%$ more likely to participate in the groundnut market than female farmers, a result that contradicts that of Burke et al. (2015). This is, however, supported partly by findings in Boughton et al. (2007), Olwande and Mathenge (2012) and Siziba et al. (2011). This observation likely reflects disparities in access to capital (for example, land and finance) between males and females. Also, males often receive the support of females on their farms more than the females do.

Number of years of schooling reduces probability of selling maize by $2.3 \%$. This observation contradicts the finding of Makhura et al. (2001) and Enete and Igbokwe (2009). The possible explanation for this is that maize is a staple and, hence, farmers with a higher level of education engage in its cultivation for consumption in order to reduce strain on family consumption budgets. Also, it is possible that education could increase the chances of the household head earning non-farm income, hence reducing dependency on income from maize sales (Enete et al. 2004).

Household size is expectedly negatively correlated with maize market participation. For an additional member of a household, the probability of selling maize decreases by $4.2 \%$. This result confirms the finding of Siziba et al. (2011) and agrees with their argument that households with large family sizes fail to produce marketable surplus beyond their consumption needs. It also confirms the finding of Makhura et al. (2001) who argue that households decide to sell when they cannot consume all they have produced and, hence, the more members the household has, the more likely most of the produce will be consumed, thereby decreasing the possibility for selling. For choice of market, larger households are $3.0 \%$ more likely to sell groundnut to a market centre. This observation is expected since groundnut is a cash crop; hence, it presents the opportunity for larger households to cash in at markets to derive higher income margins to fuel large consumption expenditures. This is easy to achieve since a larger size provides manpower to carry groundnut to market.

The yields of maize and groundnut are significantly associated with higher probability of participating in both markets, which is consistent with expectation, since higher yields are more likely to ensure marketable surplus. For an additional kilogramme yield of maize and groundnut, the probability of market participation increases by 0.1 and $1.3 \%$, respectively. This finding underscores the importance of increased yield in enhancing the chances of smallholder farmers stepping out of poverty and improving their livelihood through enhanced income from their increased participation in the market. With respect to choice of market, yields of maize and groundnut positively influence the probability of selling at market centres. For every kilogramme yield of maize and groundnut, the probability of selling at market centre increases by 0.03 and $0.1 \%$, respectively. It is expected that the transaction costs involved in selling larger outputs from larger yields in markets are relatively less than smaller outputs. That is, it is relatively cost-effective to sell smaller outputs at farmgate than at market centre. This finding is consistent with studies (for example, Fafchamps and Hill 2005; Muamba 2011) that use quantity sold in the second stage.

Access to credit has a positive influence on the probability of selling and the choice of maize market. This shows that farmers with access to credit are able to produce 
enough marketable surpluses and then sell these at market centres. Farmers who have access to credit are $48.1 \%$ more likely to sell maize and $26.7 \%$ more likely to sell at the market. One argument is that access to credit gives the farmer the economic power to cultivate on a large scale and sell at market centres. Also, the obligation of paying back the loan together with the interest provides incentive for producing beyond consumption and to incur transaction costs to reach markets to benefit from remunerative prices. While the influence of credit on participation corroborates the finding of Vance and Geoghegan (2004), it contradicts the negative influence of credit on market centre sale of maize by Muamba (2011).

Access to market information has a positive effect on the probability of selling maize and groundnut. This confirms the finding of Siziba et al. (2011) who argue that access to information reduces risk perceptions. Another possible explanation for this result could be that farmers with access to market information might be easily persuaded to sell than those without such information. Households with access to market information are 29.1 and $3.0 \%$ more likely to sell maize and groundnut, respectively, than those without market information. Access to market information does not influence the choice of market.

Membership in farmer-based organisations (FBOs) has a positive effect on the choice of markets for producers of both crops. This implies that farmers belonging to FBOs are more likely to sell maize and groundnut in market centres than at farmgate. Farmers who belong to FBOs are 51 and 54.9 \% more likely to sell maize and groundnut, respectively, at market centres than those who are not members. This is consistent with the finding of Olwande and Mathenge (2012) who argue that farmer group membership increases access to information important to production and marketing decisions. Another plausible reason could be that group membership encourages collective action and strengthens farmers' bargaining and lobbying power, thereby getting them to sell in market centres (Matungul et al. 2001). Muamba (2011) uses a similar argument to explain why farmers who belonged to rotating savings and credit associations (ROSCAs) sell at farmgate-group members are organised as cooperative and have bargaining power over village traders.

Surprisingly, access to extension services is negatively correlated with the choice of maize market. Farmers with access to extension are $47.2 \%$ less likely to sell at market centres. We expected that farmers with access to extension would be better oriented towards market sales since they are better informed not only on production but also on marketing issues. This contradicts some studies (for example, Dinar and Keynan 2001; Holloway and Ehui 2001; Hanson and Just 2001; Frisvold et al. 2001) that have found interesting results for paid extension and its impacts on smallholder agriculture. While we are not certain about this unexpected result, this may be a consequence of the ineffectiveness of extension service in Ghana, or its inability to incorporate market information in its activities. Paid extension is not widespread in Ghana and the general extension services are not effective due to logistical constraints in the midst of dispersed communities. The proportion of the sample (see Table 2) receiving extension services confirms this.

Prices of maize and groundnut positively influence the choice of maize and groundnut markets. Farmers who are faced with higher prices are, respectively, 20.8 and $110.7 \%$ more likely to sell maize and groundnut at market centres. This is consistent with the 
pickup and delivery pricing arrangements proposed by Furlong and Slotsve (1983). It also confirms the finding of Muamba (2011) regarding cotton sales. He argues that own price is a positive incentive for encouraging farmers to sell to the market. It, however, contradicts his finding on maize sales.

We find a statistically significant positive relationship between form of sale and choice of the groundnut market. Households that shelled groundnut before sale are 63.4 \% more likely to sell at a market centre. The possible reason is that shelled groundnut attracts a higher economic value at market centres than at farmgate. Farmers who go through the strenuous activity of shelling would complete the cycle by selling at market centres to fetch higher returns to compensate for their efforts.

\section{Conclusions}

This study examines market participation decisions of smallholder maize and groundnut farmers in the Upper West region of Ghana, employing a procedure that corrects for endogeneity and selectivity bias. Two crops are used to show the differences and similarities in market participation behaviours of farmers cultivating different crops. The results show that though a number of factors determine maize and groundnut producers' market participation, yield of both crops and market information are the simultaneous determinants of market participation, while age of farmer, yield of both crops, membership in FBO and own prices are the simultaneous determinants of choice of market. Only yield of both crops determines participation and choice of market simultaneously. This implies that yield is a very important decision variable in market participation of smallholder farmers, hence a key to unlocking the poverty trap that ensnares most of these farmers. From a policy standpoint, the call by researchers, institutions and governments of especially developing economies for the reorientation of policies towards market access by smallholders can be achieved through policies that enhance productivity of these smallholders. In other words, the quest for commercially oriented smallholders starts with increased yield. From the policy standpoint, the Government of Ghana through the Ministry of Food and Agriculture should make fertiliser and other agro-inputs both physically and financially accessible and also support farmers to use high-yielding crop varieties and appropriate agricultural mechanisation. This should be coupled with institutional capacity building and addressing logistical constraints.

For choice of market, yield, FBOs and price of crops are the important decision variables in encouraging market centre sales. Step one in commercialisation of smallholder agriculture is participation, which is significantly influenced by yield; the second step is selling at remunerative sources (market centres), which is influenced by these three variables (yield, FBOs and price). This implies that incentivising smallholders to incur transaction costs to reach remunerative markets lies in measures that would increase yield (as discussed already), well-functioning farmer associations and offering remunerative prices for produce. A specific policy measure is to create a farmer association unit in MoFA to engage in registration and building capacity of these organisations. Also, price incentives become inevitable in considering alternatives to market centre sales.

Indeed, we acknowledge there could be some cross-equation correlations between maize and groundnut. However, the nature of the data sets used does not allow for this 
exercise as that might not be very meaningful in this context. This thus constitutes the limitation of the current study, but it at the same time drops hint for further research.

\section{Endnotes}

${ }^{1}$ The exchange rate as quoted by www.xe.com as at 11 September 2015 was US\$1.00 = GH\$3.955.

${ }^{2} \mathrm{~A}$ recurrent embrace between empiricism in this particular field arises in the context of censored- versus truncated-regression settings. The theoretical models, for the most part, apply censored regression settings; the technicalities, especially in the case of the Gibbs sampler, require that one important fully conditional distribution is truncated (normal); and thus, while the truncation is necessary, it is brought about, compulsorily, as an intervention required by the censoring of the sales data.

${ }^{3}$ This was tested, and the results confirmed this anticipation.

${ }^{4}$ This potential endogeneity was also tested, and results showed the existence of endogeneity.

${ }^{5} \mathrm{~A}$ reviewer raised an issue about the existence of cross-equation correlations. That would have been possible if the maize and groundnut were cultivated by same households. In our case, the data were collected from predominantly maize- or groundnut-producing households so that cross-equation correlations might not have very meaningful interpretation.

\section{Abbreviations}

FBO: Farmer-based organisation; GCAP: Ghana Commercial Agriculture Project; GSS: Ghana Statistical Service; MoFA: Ministry of Food and Agriculture; ROSCAs: Rotating savings and credit associations

\section{Acknowledgements}

The first author is grateful to the International Food Policy Research Institute (IFPRI), Ghana, for providing funds for data collection and allowing for the use of the data. Authors acknowledge, with appreciation, the valuable comments made by the anonymous referees and the editor which helped improve earlier versions of this paper. The usual disclaimer, however, applies.

\section{Authors' contributions}

All authors conceived of and planned the study. BMA acquired the data and performed the statistical analysis, with guidance from PKN and HI. BMA drafted the manuscript, and $\mathrm{HI}$ and PKN critically reviewed it for important intellectual content. All authors contributed to the interpretation of results and then read and approved the final manuscript.

\section{Competing interests}

The authors declare that they have no competing interests.

Received: 25 October 2015 Accepted: 26 September 2016

Published online: 06 October 2016

References

Abu BM, Osei-Asare YB, Wayo S (2014) Market participation of smallholder maize farmers in the Upper West region of Ghana. Afr J Agric Res 9(31):2427-2435

Alene AD, Manyong VM, Omanya G, Mignouna HD, Bokanga M, Odhiambo G (2008) Smallholder market participation under transactions costs: maize supply and fertilizer demand in Kenya. Food Policy 33(4):318-328

Al-Hassan RM, Sarpong DB, Mensah-Bonsu A (2006) Linking smallholders to markets. Ghana Stategy Support Programme (GSSP), International Food Policy Research Institute (IFPRI), Background Paper No. GSSP 0001, Accra, Ghana. Available via DIALOG. http://www.pdf.usaid.gov/pdf_docs/Pnadl412.pdf. Accessed 4 Jun 2012

Bellemare MF, Barrett CB (2006) An ordered Tobit model of market participation: evidence from Kenya and Ethiopia. Amer J Agr Econ 88(2):324-337

Boughton D, Mather D, Barrett CB, Benfica R, Abdula D, Tschirley D, Cunguara B (2007) Market participation by rural households in a low-income country: an asset-based approach applied to Mozambique. Faith Econ 50(Fall 2007):64-101

Burke WJ, Myers RJ, Jayne TS (2015) A triple-hurdle model of production and market participation in Kenya's dairy market. Amer J Agr Econ 97(4):1227-1246

Casella G, George El (1992) Explaining the Gibbs sampler. Am Stat 46(3):167-174 
Dinar A, Keynan G (2001) Economics of paid extension: lessons from experience in Nicaragua Amer. J Agr Econ 83(3):769-776

Enete AA, lgbokwe EM (2009) Cassava market participation decisions of producing households in Africa. Tropicultura 27(3):129-136

Enete AA, Nweke FI, Tollens E (2004) Gender and cassava processing in Africa. Quarterly J Int Agric 43(1):57-69

Fafchamps M, Hill RV (2005) Selling at the farmgate or traveling to market. Amer J Agr Econ 87(3):717-734

Faltermeier L, Abdulai A (2009) The impact of water conservation and intensification technologies: empirical evidence for rice farmers in Ghana. Agri Econ 40(3):365-379

Frisvold GB, Fernicola K, Langworthy M (2001) Market returns, infrastructure and the supply and demand for extension services. Amer J Agr Econ 83(3):758-763

Furlong W, Slotsve G (1983) Will that be pickup or delivery? An alternative spatial pricing strategy. Bell J Econ 14(1):271-274

Gelfand A, Smith AFM (1990) Sampling-based approaches to calculating marginal densities. J Am Stat Assoc 85(410):398-409

Ghana Statistical Service (2014) Ghana living standards survey round 6 (GLSS6). Accra, Ghana. Available via DIALOG. http://www.statsghana.gov.gh/docfiles/glss6/GLSS6_Main\%20Report.pdf. Accessed 4 Oct 2016

Goetz SJ (1992) A selectivity model of household food marketing behaviour in Sub-Saharan Africa. Amer J Agr Econ 74(2):444-452

Greene WH (2008) Econometric analysis, 6th edn. Prentice Hall, New Jersey

Hanson JC, Just RE (2001) The potential for transition to paid extension: some guiding economic principles. Amer J Agr Econ 83(3):777-784

Holloway G, Barrett CB, Ehui S (2005) Bayesian estimation of the double-hurdle model in the presence of fixed costs. J Int Agric Trade Dev 1(1):17-28

Holloway G, Nicholson C, Delgado C, Ehui S, Staal S (2000) Agro-industrialization through institutional innovation: transactions costs, cooperatives and milk-market development in the East African highlands. Agri Econ 23(2000): 279-288

Holloway GJ, Ehui SK (2001) Demand, supply and willingness-to-pay for extension services in an emerging-market setting. Amer J Agr Econ 83(3):764-768

Holloway GJ, Barrett CB, Ehui S (2001a) Cross-bred cow adoption and milk-market participation in a multivariate, count-data framework. Eurostat special issue: Bayesian methods with applications to science, policy and official statistics., pp 233-242

Holloway GJ, Dorfman J, Ehui S (2001b) Tobit estimation with unknown point of censoring with an application to milk-market participation in the Ethiopian highlands. Canadian Journal of Agricultural Economics 49(2001):293-311

Holloway GJ, Ehui S, Teklu A (2008) Bayes estimates of distance to market: transactions costs, cooperatives and milkmarket development in the Ethiopian highlands. J Appl Econ 23(5):683-696

Holloway GJ, Nicholson C, Delgado C, Ehui S, Staal S (2004) A revised Tobit procedure for mitigating bias in the presence of non-zero censoring. Agricultural Economics 31(2004):97-106

Jari B, Fraser GCG (2009) An analysis of institutional and technical factors influencing agricultural marketing amongst smallholder farmers in the Kat River Valley, Eastern Cape Province, South Africa. Afr J Agric Res 4(11):1129-1137

Key N, Sadoulet E, de Janvry A (2000) Transactions costs and agricultural household supply response. Amer J Agr Econ 82(2):245-59

Makhura M-N, Kirsten J, Delgado C (2001) Transaction costs and smallholder participation in the maize market in the Northern Province of South Africa. Paper presented at the 7th Eastern and Southern Africa Regional Maize Conference, Pretoria, pp 11-15

Martey E, Al-Hassan RM, Kuwornu JKM (2012) Commercialisation of smallholder agriculture in Ghana: a Tobit regression analysis. Afr J Agric Res 7(14):2131-2141

Matungul PM, Lyne MC, Ortmann GF (2001) Transaction costs and crop marketing in the communal areas of Impendle and Swayimana, KwaZulu Natal. Dev Southern Afr 18(3):347-363

Ministry of Food and Agriculture (2011) Agriculture in Ghana: facts and figures (2010). Statistics, Research and Information Directorate (SRID), Accra, Ghana. Available via DIALOG. http://mofa.gov.gh/site/wp-content/uploads/ 2011/10/AGRICULTURE-IN-GHANA-FF-2010.pdf. Accessed 6 Jun 2012

Muamba FM (2011) Selling at the farmgate or traveling to the market: a conditional farm-level model. J Dev Areas 44(2):95-107

Olwande J, Mathenge M (2012) Market participation among poor rural households in Kenya. Paper presented at the International Association of Agricultural Economists Triennial Conference, Brasil, pp 18-24

Omiti JM, Otieno DJ, Nyanamba TO, McCullough E (2009) Factors influencing the intensity of market participation by smallholder farmers: a case study of rural and peri-urban areas of Kenya. Afr J Agric Res Econ 3(1):57-82

Reyes B, Donovan C, Bernsten R, Maredia M (2012) Market participation and sale of potatoes by smallholder farmers in the central highlands of Angola: a double hurdle approach. Paper presented at the International Association of Agricultural Economists Triennial Conference, Brazil, pp 18-24

Ricker-Gilbert J, Jayne TS, Chirwa E (2011) Subsidies and crowding out: a double-hurdle model of fertilizer demand in Malawi. Amer J Agr Econ 93(1):26-42

Siziba S, Kefasi N, Diagne A, Fatunbi AO, Adekunle AA (2011) Determinants of cereal market participation by Sub-Saharan Africa smallholder farmers. Learning Publics J Agric Env Stud 2(1):180-193

Smith MD (2003) On dependency in double-hurdle models. Stat Papers 44(4):581-595

Tanner MA, Wong W (1987) The calculation of posterior distributions by data augmentation (with discussion). J Am Stat Assoc 82:528-550

Vance C, Geoghegan J (2004) Modeling the determinants of semi-subsistent and commercial land uses in an agricultural frontier of Southern Mexico: a switching regression approach. Int Reg Sci Rev 27(3):326-347

Wooldridge JM (2002) Econometric analysis of cross section and panel data. Massachusetts Institute of Technology, Cambridge, London 